\title{
QUANTITATIVE HISTOPATHOLOGICAL ANALYSIS OF ENLARGED CELLS DERIVED FROM HUMPBACK GROUPER, Cromileptes altivelis INFECTED WITH GROUPER SLEEPY DISEASE IRIDOVIRUS (GSDIV)
}

\author{
Indah Mastuti \#, Yasmina Nirmala Asih, and Ketut Mahardika \\ Research Institute for Mariculture, Gondol-Bali
}

(Received 18 May 2010; Accepted 22 November 2010)

\begin{abstract}
Pathognomonic sign of grouper sleepy disease iridovirus (GSDIV) was proposed to be the formation of enlarged cells and necrotic cells, in which under electron microscope, it is revealed to be the inclusion body bearing cells (IBCs) and necrotic cells containing GSDIV viral particles. Spleen and kidney tissues are the major sites for formation of enlarged cells. This paper described the result of histopatological analysis of enlarged cells found in the spleen and kidney of moribund fish after GSDIV challenge. A pathogenicity test was conducted on fish stocked in two tanks for infected groups and the other two tanks for uninfected control groups (15 fish per tank). The infected groups were injected intramuscularly with $0.1 \mathrm{ml}$ of the viral inoculum. The uninfected groups were injected with the same amount of EMEM-2. The GSDIV-infected humpback grouper began to die after 6 days post infection and all died after $7 \mathrm{dpi}$, excluding one fish which had survived until the end of experimental infection periods (93\% to $100 \%$ mortality). All of the diseased fish showed massive formation of enlarged cells in their spleen, head kidney and trunk kidney. The largest number of enlarged cells was observed on head kidneys and subsequently followed by spleens, trunk kidney (2.0-200.3/field of view). This result suggested that the number of enlarged cells in the affected organs was not the direct factor that led to the mortality of fish.
\end{abstract}

KEYWORDS: GSDIV, enlarged cells, histopathology, quantitative analysis

\section{INTRODUCTION}

Iridoviruses are large double-stranded DNA viruses which have been isolated from insects, fish, amphibians and reptiles. The family Iridoviridae is currently classified into five genera: Iridovirus, Chloriridovirus, Ranavirus, Megalocytivirus, and Lymphocystivirus, each consisting of one or more virus species and strains. Members of the genera Iridovirus and Chloriridovirus infect invertebrates (i.e., insects, crustaceans, etc.). In contrast, members of the Ranavirus, Lymphocystivirus and Megalocytivirus genera infect cold-blooded vertebrates such as fish, amphibians, and reptiles (Chinchar et al., 2005). Members of the Ranavirus, Lymphocystivirus and Megalocytivirus genera are recognized as threatening viral disease in aquaculture industry. Systemic infections resulting in high mortality have been identified at least on 20 species of fish among marine and freshwater fish species (Hyatt et al., 2000).

\# Corresponding author. Research Institute for Mariculture, Jl. Br. Gondol, Kec. Gerokgak, Kab. Buleleng, Kotak Pos 140, Singaraja, Bali 81101, Indonesia. Tel.: + 6236292278

E-mail address: mastuti_indah@yahoo.com 
Megalocytivirus was newly established genus and encompasses grouper sleepy disease iridovirus (CSDIV), red sea bream iridovirus (RSIV), sea bass iridovirus (SBIV), African lampeye iridovirus (ALIV), dwarf gourami iridovirus (DGIV), Taiwan grouper iridovirus (TGIV), rock bream iridovirus (RBIV), and infectious spleen and kidney necrosis virus (ISKNV) (Chinchar et al., 2005; 2007). The epizootic caused by GSDIV occurred among brown-spotted grouper Epinephelus tauvina in Singapore and Malabar grouper E. malabaricus in Soutern Thailand (Chua, et al., 1994; Danayadol et al., 1997). Subsequently, outbreaks of GSDIV disease have been recorded in Epinephelus spp. and hybrid grouper culture (red spotted grouper E. akaara $\times$ Malabar grouper) in Taiwan (Chou et al., 1998; Chao et al., 2002). In Indonesia, GSDIV have been reported in orangespotted grouper E. coioides cultured in pen cages off North Sumatra Island (Koesharyani et al., 2001), orange-spotted grouper and Bleeker's grouper $E$. bleekeri cultured in pen cages offshore Bali Island (Mahardika et al., 2001 ) and broodstock of orange-spotted grouper stocked in broodstock tanks of Bali Island (Mahardika et al., 2001). GSDIV has also been found infecting other groupers such as the humpback grouper Cromileptes altivelis (Mahardika et al., 2004a), marbled grouper E. polyphekadion (Mahardika et al., 2004b), tiger grouper E. fuscoguttatus, sea bass (Mahardika, unpublished data) and coral trout grouper Plectropomus indicus (Mahardika et al., 2009).

The grouper fish suffering by GSDIV usually displayed lost of appetite and sleepy behavior. Moribund fish displayed a slight dark coloration on the body and a markedly swollen spleen (Mahardika et al., 2004a). Pathognomonic sign of GSDIV was proposed to be the formation of enlarged cells and necrotic cells, which under electron microscopy revealed to be inclusion body bearing cells (IBCs) and necrotic cells containing GSDIV virions with propagated within viral assembly site. GSDIV virions were a hexagonal outline with 150-200 nm in size (Mahardika et al., 2004b; 2008; 2009; Sudthongkong et al., 2002a; Miyazaki, 2007). In the present study, we focused to observe and analyze the enlarged cells derived from juvenile of humpback grouper artificially infected with GSDIV under light microscopy. This paper described the result of histopatological analysis of enlarged cells found in the spleen and kidney of moribund fish.

\section{MATERIALS AND METHODS}

\section{Virus Stock}

GSDIV stock was collected from moribund humpback grouper juveniles (70 g of average body weight) in floating net cage at Pegametan Bay, Bali Island. Diseased fish were collected in February 2010 when the outbreak of GSDIV occurred. Spleen and kidney organs were processed for viral inoculum according to Mahardika et al. (2004a) as follow, spleen and kidney tissues were homogenized in $10 x$ volume of EMEM-2 (Eagle's Minimum Essential Medium supplemented with $2 \%$ fetal bovine serum) in a glass homogenizer. The homogenate was centrifuged at $3,000 \mathrm{~g}$ for 15 minutes at $4^{\circ} \mathrm{C}$. The supernatant harvested and filtered $(450 \mathrm{~nm})$. Filtered supernatants as viral inoculum were stored in $80^{\circ} \mathrm{C}$ for further experiment processes.

\section{Pathogenicity Test}

Healthy humback grouper juveniles (mean body weight and total length, $3.6 \mathrm{~g}$ and $6.8 \mathrm{~cm}$ ) were obtained from hatchery of the Research Institute for Mariculture, Gondol Bali. A total of 60 fish were kept in four $100 \mathrm{~L}$ aquaria filled with 70-80 L of ambient sea water and aerated. One pathogenicity test was conducted using two tanks for infected groups and two tanks for uninfected control groups (15 fish per tank). The infected groups were injected intramuscularly with $0.1 \mathrm{~mL}$ of the viral inoculum. The uninfected groups were injected with the same amount of EMEM-2. Daily water exchange was about $40 \%-50 \%$ of the total water volume. Bottom of the aquarium was also cleaned daily. To prohibit viral transmission, water excess was transferred to other thank and treated with 10\% chlorine for a day, particularly when pathogenicity test were started. Cumulative mortality was examined for 21 days. Moribund and fish that had just died were removed from the tanks and dissected. At the end of the experiment, all surviving fish from all groups were removed and dissected.

\section{Stamp Smear}

A slice of spleen from individual fish right after dead was smeared in a glass slide. The smeared-slide was dried at room temperature and fixed in cold methanol for 5 minutes. Fixedslides were stained with one percent of crystal violet for a minute and than rinsed with 
aquadest, dried at room temperature, mounted in entellan, and examined under a light microscope to identify a presence of enlarged cells.

\section{Histopathological Examination}

Histological examination was emphasized on quantifying of enlarged cells on spleen and kidney. Internal organs of individual fish were fixed in buffer formalin for a week. Then, the organs samples were processed according to Gunarso (1989) with some modifications. The samples were dehydrated in alcohol $(70 \%, 80 \%$, $90 \%, 95 \%, 100 \%)$, cleared in xylene, and embedded in paraffin. All embedding process was done using automatic tissue processor. Embedded-tissues were sectioned ( 3 to $5 \mu \mathrm{m}$ ) and stained with Hematoxylin and Eosin (H\&E).

\section{Quantitative Histopathological Analysis}

The data in $0.93 \mathrm{~mm}^{2}$ area of histopathological slides per spleen and kidney section sample were examined for quantitative histopathological analysis. The data were collected in three randomly selected fields using light microscope at the instrument magnification of 400X and analyzed using an image analysis program (ACT-1 and Winroof ver. 5). Parameters of quantitative analysis comprised of number and size of enlarged cells.

\section{PCR Assay}

PCR assay to confirm the presence of GSDIV among the naturally infected fish were undertaken using primers $1-\mathrm{F}$ and $1-\mathrm{R}$ (Kurita et al., 1998). DNA templates were extracted from about $15 \mathrm{mg}$ of spleen and liver tissue using ISOGEN (Wako Nippon Gene, Osaka, Japan) according to the manufacturer's protocol. The PCR amplification was performed under conditions described previously by Mahardika et al. (2008).

\section{RESULTS AND DISCUSSION}

\section{Results}

\section{Mortality}

The GSDIV-infected humpback grouper began to die on 6 days post infection (dpi) and all had died after $7 \mathrm{dpi}$, excluding one fish which had survived until the end of experimental infection periods (93\% to 100\% mortality) (Figure 1). Death was preceded by loss appetite on day 4 followed by slightly dark coloration (Figure 2A) and sleepy behavior (lying on

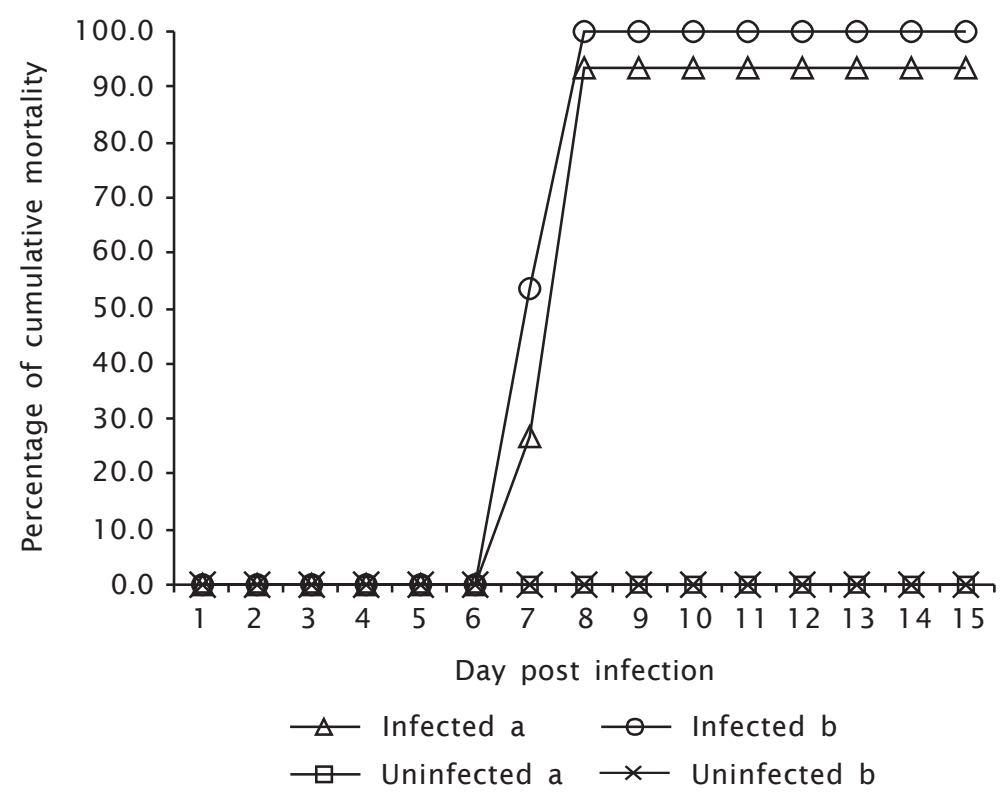

Figure 1. Cumulative mortality of fish during the experimental period. The data show each replicates in both of infected and uninfected group 

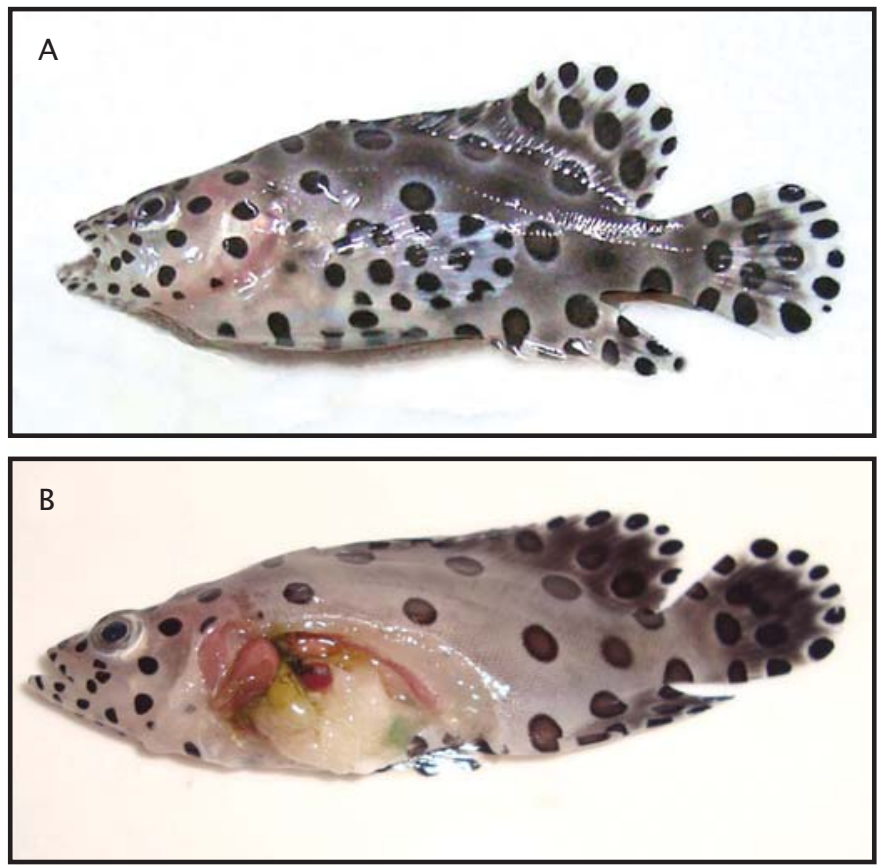

Figure 2. Cromileptes altivelis. (A) Diseased fish, displaying a slight dark coloration body. (B) Dissected diseased fish with swollen spleen

a pectoral fin) in several hours to death. All of the diseased fish showed swollen spleen and posterior kidney (Figure 2B). As expected, both of uninfected control groups showed no sign of the disease and had survived until the end of experiment (0\%).

\section{Stamp Smear}

All of the spleens of moribund fish in infected groups showed formation of enlarged cells. The sizes of these enlarged cells were bigger than blood cells and splenocyte cells, and stained purple or violet (Figure 3A and 3B). On the other hand, no enlarged cells were found in spleen-stamp of some surviving fish in uninfected control groups (3A) and one remained surviving fish in the infected groups (3D).

\section{Histopathlogycal Examination}

All of the diseased fish showed massive formation of enlarged cells in the spleen and kidney (Figure 4A and 4B). In the spleen, enlarged cells were resembled around splenic pulps and sheathed tissue. In the head kidney, the enlarged cells were generally re- sembled in the posterior sites which extend to the anterior end of trunk kidney. While in the trunk kidney, enlarged cells were found in inter tubular area. Enlarged cells also occasionally found in the liver, and heart of diseased fish from the infected groups. On the other hand, enlarged cells were not identified in all internal organs of the surviving fish from both of infected (Figure 4C) and uninfected (Figure 4D) groups, only some melano-macrophage centers were found in the hematophoetic tissue of kidney

\section{Quantitative Analysis and Measurement of Enlarged Cells}

Because enlarged cells were abundant in the spleen, head and trunk kidney, therefore quantitative analysis was focused for these organs. The abundance of enlarged cells was highly varied among individual fish, which ranged between 2.0 to 200.3 cells/field of view. The fewest numbers of enlarged cells observed on head, spleen and trunk kidney were 13.3 cells/field of view, 5.6 cells/field of view, 2.0 cells/field of view, respectively. While, the highest numbers of enlarged cells on head, spleen and trunk kidney were 200.3 

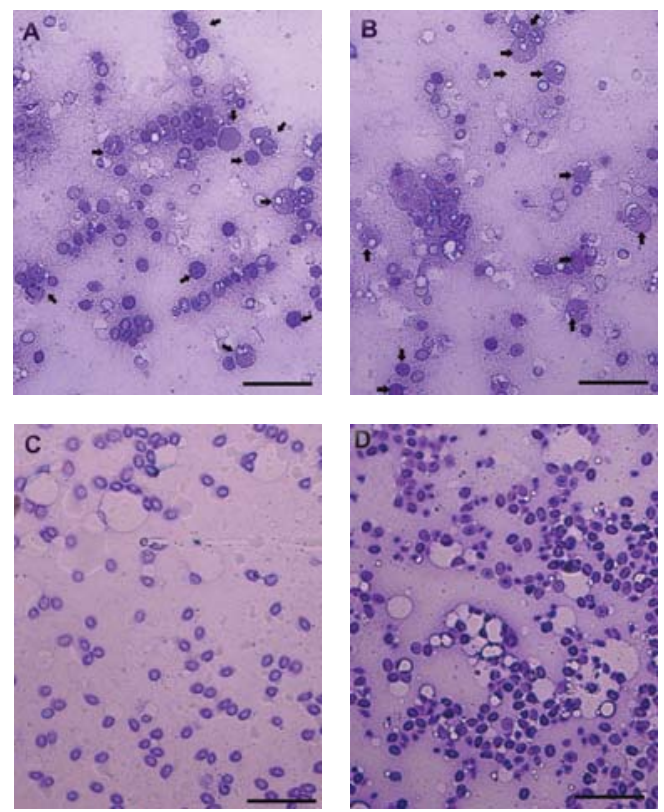

Figure 3. Stamp smear. (A-B) Smear of spleen derived from diseased fish in the infected group, shows the presence of enlarged cells (crystal violet, scale bar $=\mathrm{mm}$ ). (C) Smear of spleen derived from surviving fish in the infected group and (D) uninfected group, no enlarged cells observed in either group (Crystal violet, scale bar $=50 \mathrm{~mm}$ )
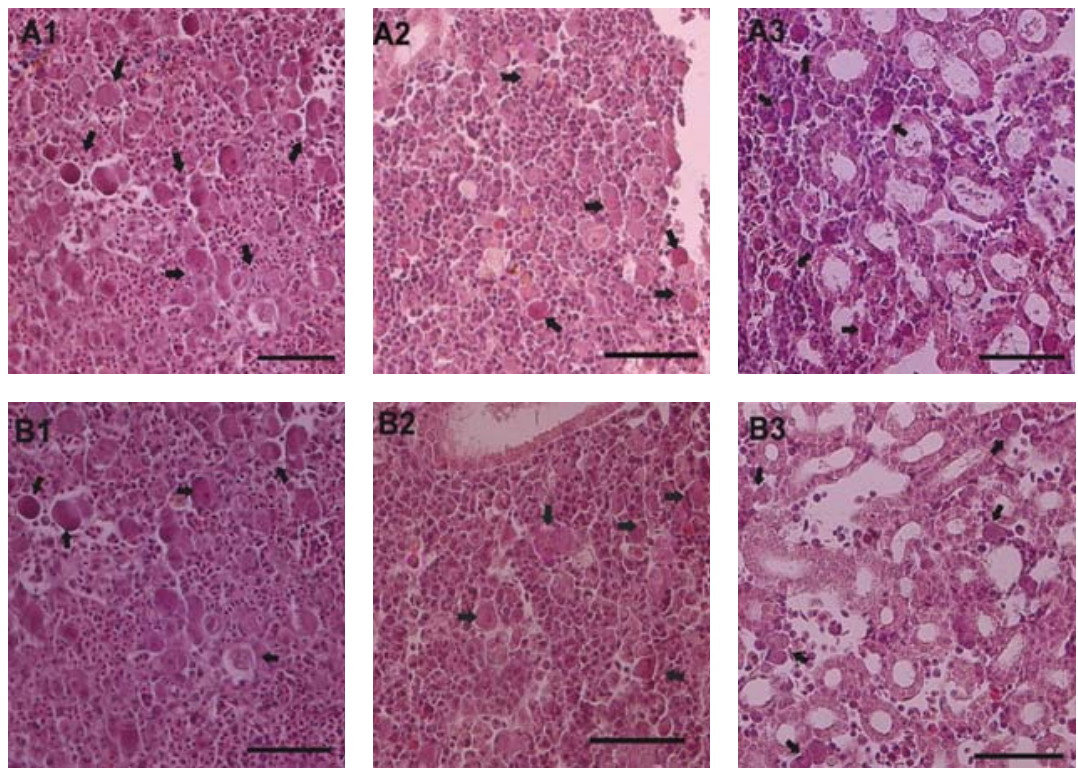

Figure 4 (A-B). Histological sections of internal organs of the diseased fish. Spleen (1), head kidney (2) and trunk kidney (3) of GSDIV-infected humpback grouper shows formation of enlarged cells (arrow) accompanied by necrotic cells (H\&E; scale bar $=50 \mathrm{~mm}$ ) 

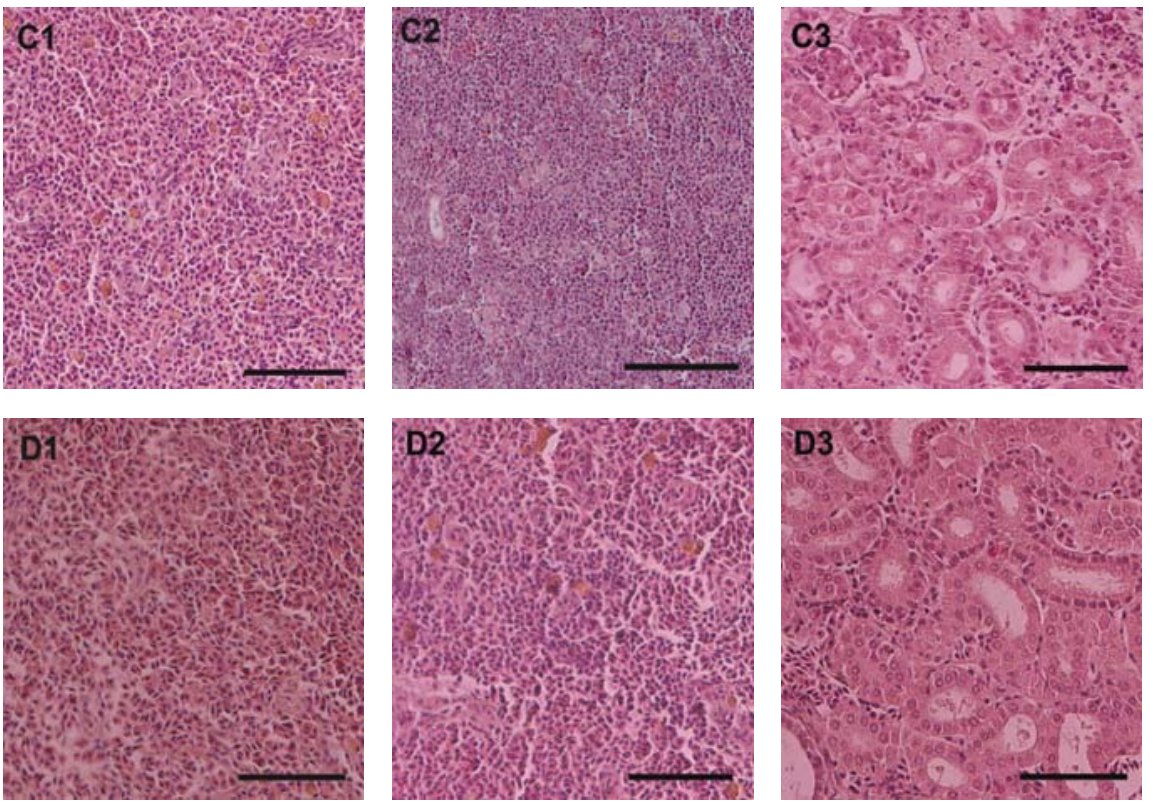

Figure 4 (C-D). Histological sections of internal organs of the surviving fish. (C) Surviving fish from the infected group shows normal spleen (1), head kidney (2) and trunk kidney (3). (D) Surviving fish in uninfected group shows no enlarged cells, only some melano-macrophage center (MMC) presented in the spleen or head kidney tissues. (H\&E; scale bar $=50 \mathrm{~mm}$ )
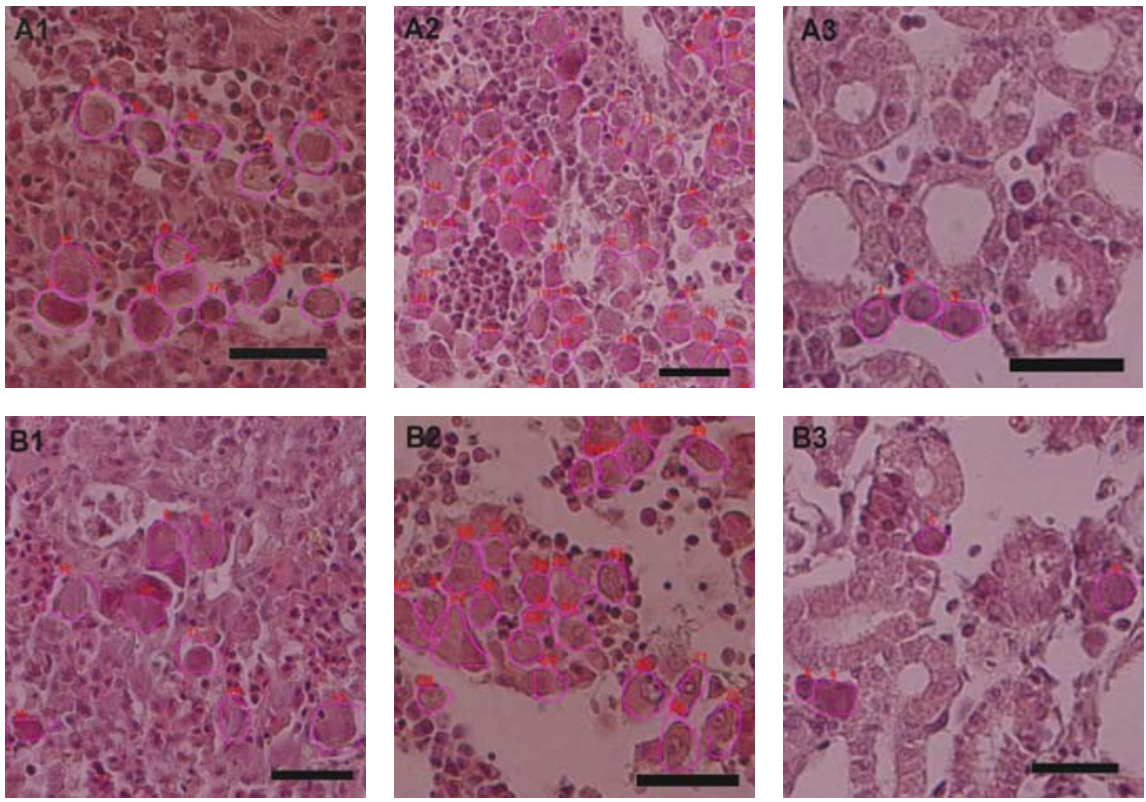

Figure 5 (A-B). Quantification and measurement of enlarged cells in the spleen, head kidney and trunk kidney of diseased fish in the infected group (H\&E; scale bar $=25 \mathrm{~mm}$ ) 
Table 1. Number of enlarged cells presents in the spleen, head kidney, and trunk kidney of individual fish

\begin{tabular}{|c|c|c|c|c|c|}
\hline \multicolumn{2}{|c|}{ Spleen } & \multicolumn{2}{|c|}{ Head kidney } & \multicolumn{2}{|c|}{ Kidney } \\
\hline A & B & A & B & A & B \\
\hline 19.0 & 7.6 & 16.6 & 13.6 & 4.3 & 5.6 \\
\hline 15.0 & 13.3 & 34.3 & 16.6 & 7.0 & 8.3 \\
\hline 9.6 & 7.0 & 47.6 & 65.0 & 7.0 & 14.6 \\
\hline 36.3 & 71.3 & 51.0 & 86.3 & 5.0 & 23.3 \\
\hline 18.3 & 16.6 & 55.0 & 82.0 & 3.0 & 13.3 \\
\hline 11.6 & 7.6 & 36.0 & 47.0 & 10.3 & 9.3 \\
\hline 18.5 & 13.0 & 16.3 & 70.3 & 2.0 & 9.3 \\
\hline 53.0 & 43.6 & 22.5 & 46.0 & 11.6 & 12.0 \\
\hline 35.6 & 5.6 & 20.0 & 62.3 & 6.0 & 12.0 \\
\hline 38.6 & 13.0 & 200.3 & 12.0 & 9.6 & 6.5 \\
\hline 41.3 & 6.3 & 24.0 & 47.0 & 2.6 & 5.0 \\
\hline 44.3 & 23.0 & 27.3 & 13.6 & 6.0 & 9.0 \\
\hline 10.6 & 19.3 & 21.3 & 17.3 & 3.6 & 17.3 \\
\hline 18.6 & 20.0 & 47.6 & 46.3 & 3.0 & 27.0 \\
\hline Survive & 12.0 & 38.0 & 33.3 & 6.0 & 10.6 \\
\hline
\end{tabular}

cells/field of view, 71.3 cells/field of view, and 27.0 cells/field of view, respectively (Table 1).

The sizes of enlarged cells were definitely different from normal cells. It also showed variation among enlarged cells (Larger cells usually appeared in amoeboid shape with fragmented nuclei). While the smaller enlarged cells usually appeared in spherical and ovoid shape with narrow cytoplasm. The diameters of enlarged cells ranged from 5.60 to $23.91 \mu \mathrm{m}$ and the total area was 24.74 to $448.98 \mu \mathrm{m}^{2}$ (Table 2).

\section{PCR assay}

The result of PCR amplification indicated that the viral agents that naturally infected fish were related to GSDIV. About 570 bp was amplified using the 1-F and 1-R primer set with DNA template obtained from affected tissues.

\section{Discussion}

Spleen and kidney were known as the target organ of megalocytivirus-infected fish and these organs were often used for challenge test and target analysis detection. The pathog-

Table 2. Size of enlarged cells comprised diameters $(\mathrm{mm})$ and total area $\left(\mathrm{mm}^{2}\right)$ in the spleen, head kidney and trunk kidney of individual fish

\begin{tabular}{|c|c|c|c|c|c|c|c|}
\hline & & \multicolumn{2}{|c|}{ Spleen } & \multicolumn{2}{|c|}{ Head kidney } & \multicolumn{2}{|c|}{ Kidney } \\
\hline & & $\begin{array}{l}\text { Diameter } \\
\qquad(\mu \mathrm{m})\end{array}$ & $\begin{array}{c}\text { Total } \\
\text { area }\left(\mu \mathrm{m}^{2}\right)\end{array}$ & $\begin{array}{l}\text { Diamet er } \\
(\mu \mathrm{m})\end{array}$ & $\begin{array}{c}\text { Total } \\
\text { area }\left(\mu \mathrm{m}^{2}\right)\end{array}$ & $\begin{array}{l}\text { Diameter } \\
\qquad(\mu \mathrm{m})\end{array}$ & $\begin{array}{c}\text { Total } \\
\text { area }\left(\mu \mathrm{m}^{2}\right)\end{array}$ \\
\hline & Mean & 11.47 & 107.72 & 11.26 & 103.50 & 10.19 & 87.19 \\
\hline \multirow[t]{2}{*}{$A$} & Max & 17.78 & 248.16 & 19.98 & 313.60 & 15.07 & 178.44 \\
\hline & Min & 5.69 & 25.45 & 6.62 & 34.43 & 5.60 & 24.59 \\
\hline \multirow{3}{*}{ B } & Mean & 13.34 & 148.72 & 13.86 & 155.29 & 11.57 & 110.78 \\
\hline & $\operatorname{Max}$ & 23.91 & 448.98 & 21.17 & 352.10 & 23.03 & 416.61 \\
\hline & Min & 5.61 & 24.74 & 8.55 & 57.89 & 5.96 & 27.95 \\
\hline
\end{tabular}


nomonic signs of megalocytivirus-infected fish were designated as formation of enlarged cells and necrotic cells (Inouye et al., 1992; Jung et al., 1997; Sudthongkong et al., 2002a; b; Mahardika et al., 2001; 2004; 2008; 2009; Chao et al.,2002, 2004; He et al., 2001; Jung \& Oh., 2000; Miyazaki, 2007). The result of this study was in accordance those studies where a large numbers of enlarged cells were found in the kidney and spleen.

The data showed that the head kidney had the highest concentration of enlarged cells (up to 200.3 cells/ field of view). However, several studies found that spleen was the initial site of histopathological change in megalocytivirus-infected fish. The emergence of enlarged cells in other organs especially in the trunk and head kidney was the second peak, where at this time the number of necrotic cells increase and macrophage cells remove the necrotic (Chao et al., 2004). The present result assumed that the number of enlarged cells in the spleen was decreased when the viral particles accumulated in the other organs through circulatory systems. The head kidney might be more suitable for the viral particles to replicate than in the trunk kidney, as less hematopoetic tissue composed the trunk kidney.

Enlarged cells are the character of megalocytivirus infection. Recently, the ultrastructural of enlarged cell have been well described under the electron microscopic study. They can be divided into two types of enlarged cell; inclusion body bearing cells (IBCs) and cells with fragmented nucleus (Mahardika \& Miyazaki, 2009). Moreover, Mahardika et al. (2004a) determined that massive formation of enlarged cells were inclusion body-bearing cells (IBCs) which consisted of mature IBCs, ballooning degenerated IBCs and atypical IBCS like swollen cells. Mature IBCs had an enlarged inclusion body containing a developed virus assembly site (VAS). The host cell cytoplasm was marginally located and protruded with the boundary membrane into the inclusion body. The VAS had an electron-lucent matrix with abundant fine granules, and contained many virions, hexagonal in outline with an electrondense core and 180 to $200 \mathrm{~nm}$ in size. Ballooning, degenerated IBCs had an inclusion body with the electronlucent matrix containing degenerated and fragmented organelles and a decreased number of virions in the VAS. While, atypical IBCs had an unusual inclusion body, like a swollen cell in appearance, with the elec- tron-lucent matrix containing abundant granules, fewer mitochondria and $r E R$, a swollen nucleus-like structure with little content and its degeneration without virion assembly.

\section{CONCLUSION}

The number of enlarged cells in the spleen, head kidney and trunk kidney was highly varied among individual fish but it always presents in these organs This result suggest that the number of enlarged cells in the affected organs was not the direct factor that led to mortality of the fish. The emergence of enlarged cells in various organs might be resulting in different manifestation. Within the circulatory system, these cells are trapped in the capillaries, especially in the gills, resulting in insufficient gas exchanged and finally lead in the death of fish. Recent study lead by Mahardika et al. (2009) concluded that severe necrosis of spenocytes due to GSDIV-infection contributed the diseased fish to die.

\section{REFERENCES}

Chao, C.B., Yang, S.C., Tsai, H.Y., Chen, C.Y., Lin, C.S., \& Huang, H.T. 2002. A Nested PCR for the Detection of Grouper Iridovirus in Taiwan (TGIV) in Cultured Hybrid Grouper, Giant Seaperch and Largemouth Bass. J. Aquat. Anim. Health, 14: 104-113.

Chao, C.B., Chen, C.Y., Lai, Y.Y., Lin, C.S., \& Huang, H.T. 2004. Histological, ultrastructural, and in situ hybridization study on enlarged cells in grouper Epinephelus hybrids infected by grouper iridovirus in Taiwan (TGIV). Dis. Aquat. Org., 58: 127-142.

Chinchar, G., Essbauer, S., He, J.G., Hyatt, A., Miyazaki, T., Seligy, V., \& Williams, T. 2005. Family Iridoviridae. In: Fauquet,C.M., M.A. Mayo, J. Maniloff, U. Desselberger, and L.A. Ball (eds) Virus Taxonomy. Classification and Nomenclature of Viruses. Eighth Report of the International Committee on the Taxonomy of Viruses. Academic Press, San Diego, p. 145-162.

Chinchar, V.G., Hyatt, A., Miyazaki, T., \& Williams, T. 2007. Family Iridoviridae: Poor viral relations no longer. CTMI, 18 October, p. 1 64.

Chou, H.Y., Hsu, C.C., \& Peng, T.Y. 1998. Isolation and characterization of a pathogenic iridovirus from cultured grouper (Epinephelus sp.) in Taiwan. Fish Pathol., 33: 201-206. 
Chua, F.H.C., Ng, M.L., Ng, K.L., Loo, I.J., \& Wee, J.Y. 1994. Investigation of Outbreaks of A Novel Disease, Sleepy Grouper Disease, Affecting in Brown Spotted Grouper Epinephelus tauvina Forskal. J. Fish. Dis., 17: 417-427.

Danayadol, Y., Direkbusarakom, S., Boonyaratpalin, S., Miyazaki, T., \& Miyata, M. 1997. Iridovirus Infection in Brown Spotted Grouper Epinephelus malabaricus Cultured in Thailand. In: Flegel T.W, MacRae, I.H. (eds). Disease in Asian Aquaculture III. Asian Fisheries Society, Manila, p. 67-72.

Gunarso, W. 1989. Mikroteknik. Departemen Pendidikan dan Kebudayaan, Direktorat Jenderal Pendidikan Tinggi Pusat Antar Universitas IImu Hayat. Institut Pertanian Bogor, $117 \mathrm{pp}$.

He, J.G., Deng, M., Weng, S.P., Li, Z., Zhou, S.Y., Long, Q.X., Wang, X.Z., \& Chan, S.M. 2001. Complete genome analysis of the mandarin fish infectious spleen and kidney necrosis iridovirus. Virology, 291: 126-139.

Hyatt, A.D., Gould, A.R., Zupanovic, Z., Cunningham, A.A., Hengstberger, S., Whittington, R.J., Kattenbelt, J., \& Coupar, B.E.H. 2000. Comparative studies of piscine and amphibian iridoviruses. Arch. Virol., 145: 301-331.

Inouye, K., Yamano, K., Maeno, Y., Nakajima, K., Matsuoka, M., Wada, Y., \& Sorimachi, M. 1992. Iridovirus infection of cultured red sea bream, Pagrus major. Gyobyo Kenkyu, 27: 19-27.

Jung, S.J., Miyazaki, T., Miyata, M., Danayadol, Y., \& Tanaka, S. 1997. Pathogenicity of iridovirus from Japan and Thailand for the red sea bream Pagrus major. Fish Sci., 63: 735-740.

Jung, S.J. \& Oh, M.J. 2000. Iridovirus-like Infection Associated with High Mortalities of Striped Beakperch Oplegnathus fasciatus (Temminck et Schlegel) in Southern Coastal Areas of The Korean Peninsula. J. Fish. Dish., 23: 223-226.

Kurita, J., Nakajima, K., Hirono, I., \& Aoki, T. 1998. Polymerase chain reaction (PCR) amplification of DNA of red sea bream iridovirus (RSIV). Fish Pathol., 33: 17-23.

Koesharyani, I., Roza, D., Mahardika, K., Johnny F., Zafran, \& Yuasa K., 2001. Marine Fish and Crustacean Disease in Indonesia. In Sugama, K., Hatai, K., Nakai, T. (eds) Manual for Fish Disease Diagnosis II. Gondol Marine Research for Mariculture and Japan
International Coorporation Agency, Bali, p 5-7.

Mahardika, K., Koesharyani, I., Sugama, K., Priyono, A., \& Yuasa, K. 2001. Histopathological Study of Iridovirus Infection in Eoineohelus coioides and Epinephelus bleekeri. Proc Maricul Technol Sea Farming Dev. Japan International Coorporation Agency, Jakarta, p. 334-341 (in Indonesian with English abstrack).

Mahardika, K., Zafran, Yamamoto, A., \& Miyazaki, T. 2004a. Susceptibility of juvenile humpback grouper (Cromileptes altivelis) to grouper sleepy disease iridovirus (GSDIV). Dis. Aquat. Org., 59: 1-9.

Mahardika, K., Zafran, Roza, D. \& Johnny, F. 2004 b. Susceptibility test of the orange spotted grouper, Epinephelus coioides and marbled grouper, Epinephelus microdon to the iridovirus infection. J. Pen. Perik. Indonesia. 10(2): 83-88 (in Indonesian in English abstract).

Mahardika, K., Haryanti, Muzaki, A., \& Miyazaki, T. 2008. Histopathological and ultrastructural features of enlarged cells of humpback grouper Cromileptes altivelis challenged with Megalocytivirus (Family Iridoviridae) after vaccination. Dis. Aquat. Org., 79: 163-168.

Mahardika, K. 2009. Electron Microscopic Study on Enlarged Cells Derived from Red Sea Bream Iridovirus (RSIV, Genus Megalocytivirus, Family liridoviridae)-InfectedRed Sea Bream Pagrus major. Indonesian Research Journal, Inpres. 4:1. p. 53-56.

Mahardika, K., Muzaki, A., \& Suwirya, K. 2009. Pathogenecity of grouper sleepy disease iridovirus (GSDIV: Megalocytivirus, family Iridoviridae) to coral trout grouper Plectropomus leopardus. Indonesian Research Journal, Inpres. 4:2. p. 121-130.

Mahardika, K. \& Miyazaki, T. 2009. Electron microscopic features of cultured grunt fin cells infected with Megalocytivirus. Aquaculture Sci., 57: 9-18.

Miyazaki, T. 2007. Color Atlas of Fish Histopathology, Vol. 2. Shin-Suisan Shimbun-Sha, Tokyo, Japan, p. 325-335.

Sudthongkong, C., Miyata, M., \& Miyazaki, T. 2002a. Iridovirus disease in two ornamental tropical freshwater fishes: African lampeye and dwarf gourami. Dis. Aquat. Org., 48: 163-173.

Sudthongkong, C., Miyata, M., \& Miyazaki, T. 2002 b. Viral DNA sequences of genes en- 
coding the ATPase and the major capsid protein of tropical iridovirus isolates which are pathogenic to fishes in Japan, South
China Sea and southeast Asian countries. Arch. Virol., 147: 2,089-2,109. 